\title{
ETHICS IN THE GOSPEL OF JOHN
}

\author{
DISCIPLESHIP AS MORAL PROGRESS ${ }^{1}$ \\ Sookgoo Shin \\ (sookgooshin@gmail.com)
}

This study seeks to challenge the dominant scholarly view of John's ethics as an ineffective and unhelpful companion for moral formation. The Gospel of John has been an unwelcome outsider when it comes to the discussion of ethics since it has been accused of being morally bankrupt, not ethical enough to be included in New Testament ethics, and a puzzling book - indeed, a major challenge - for ethical enquiry. No one has been, however, more sceptical about the value of John's ethics than Wayne Meeks, whose criticisms have contributed significantly to this negative view. In order to demonstrate the inadequacy of such claims, this study aims to identify the undergirding ethical dynamic that shapes John's moral structure by bringing out the implicit ethical elements that are embedded throughout John's narratives, and thus suggests a way to read the whole Gospel ethically and appreciatively of its literary characteristics.

Chapter 1 surveys recent scholarship on John's ethics and categorises the works into three distinguishable groups based on their general methodological objectives: 1) The Role of the Law in John's Ethics; 2) Exploring Possible Conceptual or Historical Backgrounds for John's Ethics; 3) Linguistic-Semantic Analysis of Johannine Terms to Expose Hidden Ethical Meanings. The overview of recent literature on John's ethics identifies the primary reasons that make the study of John's ethics problematic: John does not use the ethical language that is commonly found in other New Testament books, and most of the terms we find in the Gospel have been understood either theologically or christologically. Furthermore, there are no ethical chapters in the Gospel of John like the Sermon on the Mount or the paraenetic sections

1 Sookgoo Shin, 'Ethics in the Gospel of John: Discipleship as Moral Progress' (Ph.D. thesis, University of Cambridge, 2017); supervisor Professor Judith Lieu. 
in Paul's letters; ethical elements are spread throughout the Gospel so that it can seem almost impossible to find a single ethical idea that can capture John's overall moral paradigm. In light of these difficulties, a survey of recent scholarship on John's ethics suggests that the main aim of this study should be to examine whether ethical values or implications can be drawn out from John's narratives, which are heavily laden with Christo-theological dimensions.

Chapter 2 explores extensively the moral landscape of the GraecoRoman world and argues that the ancients had a vastly different moral framework, which would obviously cause difficulty for modern readers trying to draw ethical implications from ancient literature like John's Gospel. Based on such findings, this study suggests that John's ethics should be approached and understood within contemporary ethical and literary conventions, and finds Plutarch, whose literary (rhetorical) practices and moralising techniques turn out to be helpful in investigating John's ethics, to be a suitable model. This study also utilises another important aspect of Plutarch's ethical principles, namely 'moral progress', which basically suggests that individuals begin their moral development through worldview transformation, and this through the study of philosophy, which culminates ultimately in behavioural changes. In light of the ancient understanding of moral progress, this study contends that the process of discipleship found in John's Gospel should be understood in this way. In order to argue for such an affinity between moral progress (Plutarch) and discipleship (John), this study pays attention to the fact that there is a clear contrast in terms of narrative atmosphere between chapters 1-12 and 13-17. For example, in the first 12 chapters, we see that Jesus interacts not only with his disciples, but also with the crowds, who are often hostile to his teachings; entering the second half of the Gospel, we find that Jesus exclusively interacts only with his own disciples. More importantly, Jesus' teaching also dramatically changes. The characteristics of Jesus' teachings in the first 12 chapters are apologetic, worldview transforming, and identity forming, but in the second half of the Gospel they become more personal and focused on the practical side of discipleship - Jesus urges his disciples to imitate him. In other words, Jesus' invitation to imitation (chs 13-17) finds its foundation in Christology (chs 1-12; i.e. Jesus' identity, mission, and relationship to the Father, etc.); only those who are truly transformed 
by Jesus' teachings about his identity and mission can move on to the next level of discipleship - imitating Jesus.

Having laid the groundwork, the study moves on to investigate the first 12 chapters of the Gospel to see how John tries to persuade readers to have faith in Jesus as the Son of God by encouraging them to adopt Jesus' teachings and worldview. As previously noted, it is imperative for individuals to possess a right set of values before moving on to imitate moral traits exemplified by a noble figure. Hence John's readers must reevaluate their old worldview and adopt that reflected in the Gospel in order to understand its message correctly. Without aligning one's worldview to that of the Gospel, one would inevitably end up misunderstanding the words and deeds of Jesus, and thus failing to move further in discipleship. Though the author utilises many different stories to transform the readers' worldview, due to limited space this study focuses primarily on three figures: Nicodemus (Chapter 3), the Samaritan woman (Chapter 4), and the blind man (Chapter 5). In each episode, the study refers to Plutarch's writings whenever necessary to show that the kind of transformation that the author intends is not only religious (spiritual) but also ethical in light of the ancient literary practice of shaping readers' moral outlook. It is important to note that it does not intend to trace a particular character's journey of discipleship, but rather to examine how the overall Gospel shapes the readers' moral worldview and thus their behaviour.

Chapter 6, which is the longest chapter of the study, focuses on how individuals who have made a commitment to Jesus are expected to move on in their journey of discipleship by imitating the words and deeds of Jesus, as demonstrated in the Farewell Discourse. This study discovers that Jesus' footwashing in chapter 13 plays a strategic role not only in setting the tone and context for the rest of the Farewell Discourse, but also in introducing readers to the notion of 'imitation' as an instrument for moral formation. What becomes clear in the lengthy discussion on the nature and the scope of imitation is that the ancients do not encourage the blind copying of their heroes' actions found either in real life or in biographies, but rather creative imitation of the essence of virtues demonstrated by those heroes. Similarly, John's readers are not simply called to imitate Jesus' footwashing mechanically, but to embody the essence of Jesus' actions creatively and in a way that surpasses historical, cultural, and geographical constraints. Again, limited space does not allow for a complete exegesis of the entire 
Farewell Discourse, but Chapter 6 confines its attention only to the $\kappa \alpha \theta \omega ́ \varsigma$ ('just as', 'as') passages, which capture the essential moral traits that Jesus wants his followers to imitate. The conjunction $\kappa \alpha \theta$ ó plays a strategic role, which helps us identify the four moral traits (love, mission, unity, and otherworldly status) displayed by Jesus.

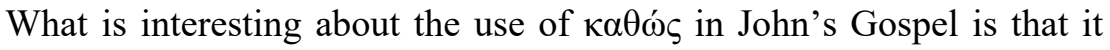
takes a nuance of analogy only in the second half of the Gospel, and this shows that imitating Jesus is expected only of those who have already made significant progress in their journey of faith. The conclusion reached at the end of this study is that John portrays the journey of discipleship in a manner similar to the process of moral progress, which contends that worldview transformation precedes behavioural changes.

Though John's Gospel may not contain many explicit ethical rules, the absence of such concrete directives - ironically - makes John's ethics timeless. Instead of giving a set of specific behavioural guidelines, John's ethics first focuses on fundamental human qualities that draw readers' attention to the more profound questions that deal with one's being, worldview, and identity. These are the qualities that are applicable to anyone regardless of time, situation, and social status. Moreover, having ethical values embedded within narratives has the benefit of providing the moral framework that is connected to the larger story, which offers a solid Christo-theological foundation for readers' newly acquired moral vision. When the Gospel is read in such a way, John's narratives become an overflowing stream of moral insight that is neither fragmentary nor isolated, but is rather shared and confirmed by the wider believing community that is also transformed by the same teachings and examples of Jesus. What readers find at the end is a paradox: if readers read the Gospel for spiritual formation, they will naturally end up reading it for moral formation, since in John spiritual awakening always leads to moral awakening. 